\title{
Studies on bacterial blight of cotton with different weather parameters under south Gujarat condition
}

PRASHANT B. SANDIPAN*, P.V. PATIL, R.D. PATEL, G.R. BHANDERI, H.R. DESAI AND B.G. SOLANKI

Main Cotton Research Station (N.A.U.) SURAT (GUJARAT) INDIA

\section{ARITCLE INFO}

Received : 23.08 .2016

Revised : 04.09 .2016

Accepted : 18.09.2016

\section{KEY WORDS :}

Bacterial blight, Epidemiological, Xanthomonas, campestris pv. malvacearum, Environmental parameters, Correlation
*Corresponding author: Email : prashantsandipan@gmail.com

\begin{abstract}
Main objective of present study is to study the progress of the bacterial blight disease of cotton (BLB), caused by Xanthomonas campestris pv. malvacearum (Smith) dye, with relation to the environmental parameters. This is a common disease affecting the growth, development and yield of cotton. A field trial was conducted to determine the influence of environmental factors viz., rainfall periods, temperature and humidity on development of disease. Bacterial blight disease was recorded with its appearance and subsequently at weekly interval till it prevailed on G. Cot. Hy. 12. The result presented and indicates that the disease was first appeared in $36^{\text {th }}$ Met. week (First week of September) with 1.37 per cent intensity and prevailed upto $48^{\text {th }}$ Met. week i.e. last week of November $(1.75 \%)$ with its peak during $42^{\text {nd }}$ week i.e. $2^{\text {nd }}$ week of October $(24.50 \%)$.

How to view point the article : Sandipan, Prashant B., Patil, P.V., Patel, R.D., Bhanderi, G.R., Desai, H.R. and Solanki, B.G. (2016). Studies on bacterial blight of cotton with different weather parameters under south Gujarat condition. Internat. J. Plant Protec., 9(2) : 547-550, DOI : 10.15740/HAS/IJPP/9.2/547-550.
\end{abstract}

